Vol.10, No.2, pp. 23-40, 2022

ISSN 2054-6351 (print),

ISSN 2054-636X (online)

\title{
EVALUATION OF SOC IN A PINE AND BROADLEAVED MIXEDFOREST SOIL OF A NATURE RESERVE IN GUANGDONG PROVINCE CHINA
}

\author{
1 *Christian Toochi Egbuche, Su Zhiyao² ${ }^{2}$ Okereke-Ejiogu Ngozi .E', Azubuike N.O ${ }^{1}$, \\ I.E.Duruanyim ${ }^{1}$, Duru I.C ${ }^{1}$, Marcellin Robertson ${ }^{1}$, and Okoi U. Ina Jnr ${ }^{1}$ \\ ${ }^{1}$ Department of Forestry \& Wildlife Technology, \\ School of Agriculture and Agricultural Technology \\ Federal University of Technology Owerri Imo State, Nigeria \\ ${ }^{2}$ College of Forest Ecology, \\ South China Agricultural University Guangzhou, China \\ ${ }^{3}$ Dept of Agricultural Extension, School of Agriculture and Agricultural Technology \\ Federal University of Technology Owerri Imo State, Nigeria
}

\begin{abstract}
Citation: Christian Toochi Egbuche, Su Zhiyao, Okereke-Ejiogu Ngozi .E, Azubuike N.O, I.E.Duruanyim, Duru I.C , Marcellin Robertson , and Okoi U. Ina Jnr(2022) Evaluation of Soc in a Pine and Broadleaved Mixed Forest Soil of a Nature Reserve in Guangdong Province China, British Journal of Environmental Sciences, Vol.10, No.2, pp. 23-40
\end{abstract}

\begin{abstract}
The concern on the role of soil in the global carbon budget and effects of SOC decline on soil quality has been incorporated in international treaties. In Article 3.4 of the Kyoto protocol, soil and forests has been identified as a potential sink of carbon (SOC) that nations tends to establish greenhouse gas inventories and carbon management authorities. Sanchading Nature Reserve Forest Ecosystem and Wildlife study site covers a total area of 2044.2 hectares covering high specie richness of about 1,100 kinds of plants. Soil chemical analysis of the reserve site was conducted at specific depth $10-25 \mathrm{~cm}$ and 25 $50 \mathrm{~cm})$. Effect of plant stand types based on broad pine and broadleaved mixed forest $(30.24 \pm 1.35,11.71$ of 4.49 coefficient variations at $0-25 \mathrm{~cm}$ depth, while $25-50 \mathrm{~cm}$ was 26.65 $\pm 2.49,21.53$ at 9.33). Correlation analysis of NMC, BD, pH, EC and chemical properties showed highest at $51 \mathrm{~g} * \mathrm{~kg}$ and $49 \mathrm{~g} * \mathrm{~kg}$ at both depths. Duncan's critical evaluation

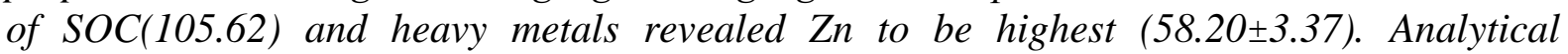
approaches of SOC and associated factors were comparatively reviewed while the study site shows that correlation analysis of the influence of soil properties on SOCc and SOCd (O$50 \mathrm{~cm}$ ) indicated less disturbances and good forest management regime were in place. SOC concentration and effect of pollution and other forest soil environmental disturbances shows negative impact on terrestrial ecosystems. Cumulative evaluation of SOC distribution further supports that pine and broadleaved mixed forest stand exhibits high potential of carbon sequestration.
\end{abstract}

KEYWORDS: SOC, analytical approaches of SOC, pine and broadleaved mixed forest, nature reserve, carbon management

\section{INTRODUCTION}

Regional and national evaluation of Soil Organic Carbon density, its concentration and distributions among forest regimes is crucialfor tropical and sub-tropical forest ecosystems management. Soil Organic Carbon and its influencing factors have become of interest to both

ECRTD-UK https://www.eajournals.org/

Journal level DOI: https://doi.org/10.37745/bjes.2013 
Vol.10, No.2, pp. 23-40, 2022

ISSN 2054-6351 (print),

ISSN 2054-636X (online)

soilscientists and policymakers at recent times for their ability to mitigate $\mathrm{CO}$ 2. Climate change concerns have resulted to a greater interest in terrestrial ecosystems management. This raises the question of how good forest and soil management can be used to sequester C.It has been documented that the mass of organic carbon in soils exceeds the mass of organic carbon in living vegetation by two or three times [1], which amounted to $1500 \mathrm{Pg}$ in soil globally [2];[3]. It becomes an interesting area of investigation on how forest management regimes at regional and spatial scale can be sustained. Recently, the concern on the role of soil in the global carbon budget and effects of SOC decline on soil quality has been incorporated in international treaties. The decline of soil organic matter (SOM) is considered as one of the eight threats to soil degradation. In line with Article 3.4 of the Kyoto protocol, soil and forests has been identified as a potential sink of carbon (SOC) for which most nations are beginning to establish greenhouse gas inventories and carbon management authorities. It is anticipated that climate change and climate variability will trigger some vulnerability frontline challenges.Soil organic matter is a key and an active attribute of soil quality [4][5]because it influences nutrient cycling, soil structure, water availability, and other important soil properties [6] and [7]. Increase in soil $\mathrm{C}$ and the basic constituent of soil organic matter is important in forest soil management. It has been accounted that soil store a significant fraction of the carbon (C) involved in carbon cycle. Global soils contain approximately $1,500 \mathrm{Pg} \mathrm{C}(1 \mathrm{Pg}=1 \times 1015 \mathrm{~g})$ and can act either as net sources or net sinks of atmospheric $\mathrm{CO} 2$ [8]. Considering existing scientific studies on terrestrial ecosystems management and total carbon accumulation; more investigations need to be conducted on soils as a significant component of carbon storage that has been observed also by [9][10]; [11] and [12].SOC density and concentration evaluated at regional assessment among forests primarily raises the understanding for terrestrial ecosystems and good management practices in soil and forest management. Strategies for organic carbon management in soils and forests are areas that have been studied by [13] [14] [15]. The rate of SOC density and concentration varies with the vegetation stand type and management history and conditions. It becomes an important venture to further study organic carbon in Deqing Sanchading Nature Reserve South China, which has been considered very vital in the function of ecosystems and agroecosystems. Furthermore, [15]reported that loss of SOC may result in reduction to soil fertility, forest health, land degradation and larger extent desertification. Soil organic carbon content in any forest regime can be increased in three major ways, such include (a) by improved forest management regime within a land use system, (b) by introduction and conversion of a particular land use to another land use that has higher potential of carbon stocks, and (c) by increasing and improve carbon content in harvested forest products. An assemblage of major terrestrial ecosystems, carbon sequestration, in the essence of this study, terrestrial biosphere refers to living and dead plants and soils. Significant progress has been made to estimate the potential for $\mathrm{C}$ sequestration on site, regional, and national scales for agricultural land [16] [17] [18] [19]; [20] forests [21]; [22]; [23], and grasslands and pasture [24] and [25];[26]. Terrestrial ecosystems are reported by [27], in [28], to remove approximately a net of 60 billion tons of carbon from the atmosphere each year referred as "Net Primary Productivity" (NPP). Jonathan [29] had documented and in graphics reported changes in the $\mathrm{C}$ cycle of terrestrial ecosystems directly affect the atmosphere. Currently, the terrestrial biosphere is a net sink of atmospheric $\mathrm{CO} 2$. Variations in climate and atmospheric chemistry, however, could alter this process. The terrestrial biosphere feedback mechanisms 
Vol.10, No.2, pp. 23-40, 2022

ISSN 2054-6351 (print), ISSN 2054-636X (online)

explains the absorption of $\mathrm{CO} 2$ through photosynthesis and accumulates $\mathrm{C}$ in living biomass, though some is released back to the atmosphere through plant respiration, and the rest is used to build biomass.

\section{METHODOLOGY}

\section{Site description and experimental designofDeqing Sanchading Nature Reserve}

Deqing County is located in Zhaoqing city, Guangdong Province. The site is a nature reserve buffer zone, at longitude $112^{\circ} 01^{\prime} \mathrm{E}$ and latitude $23^{\circ} 26^{\prime} \mathrm{N}$ (fig. 1). The county is surrounded by villages and towns. The county covers a total area of 2044.2 hectares and where Sanchading Nature Reserve forest ecosystem and wildlife nature reserve is located. The nature reserve location consists mainly of granite soil and sandstone rock in a medium to low mountainous landscape. The highest elevation is $700 \mathrm{~m}$, lowest elevation is $120 \mathrm{~m}$, relative elevation 580 $\mathrm{m}$, and the general mountain slope is $30-40^{\circ}$ though some parts of the upper slope peak reaches $60-70^{\circ}$. There is high specie richness at the site with more than 1100 kinds of plants. The forest site has state protection of both rare and endangered plant species. Such plant species include the camphor tree Cinnamomum camphora, wood frame Erythrophloeum fordii, Cibotium barometz, Cyatheaceae Cyltbee spinuldosa, and Cyatheaceae Cyathea podophylla, Camptotheca acuminata decne, Taiwan Cycas Cycas taiwaniana carruth cedar and bald Taiwania flousiana Gaussen. At the provincial level, forest types are designated as follows: 1) subtropical evergreen broad-leaved forest (mainly at the core area that forms the rich subtropical plant species); 2) The mixed conifer forest mainly located in the buffer zone within the pine and subtropical evergreen broad leaved forest tree species.

\section{Site characteristics and management history}

The selected forest location across the province provided a geographical coverage across the region. The site was selected to achieve specific and regional SOC assessment among the forest management regime and plant vegetation species. The background of the site, forest regime, stand types and geographical location is described and furthermore, the forest site and history of management that gave an insight of the present forest stand type is shown in Table 1 and Figure 1 showing the location of Sanchading Nature Reserve Forest.

Table 1 Forest site description, characteristics and summary of the management history

\begin{tabular}{|c|c|c|c|}
\hline Forest Site & Stand type & Management regime & Geographic location \\
\hline $\begin{array}{l}\text { Deqing Sanchading } \\
\text { Nature Reserve }\end{array}$ & $\begin{array}{c}\text { Pine and } \\
\text { broadleaved mixed } \\
\text { forest }\end{array}$ & $\begin{array}{l}\text { Formerly a tree } \\
\text { farm, now } \\
\text { protected, less } \\
\text { disturbance } \\
\text { Managemer }\end{array}$ & $\begin{array}{l}23.28 \mathrm{~N} ; 111.9 \mathrm{E} \\
\text { thistory }\end{array}$ \\
\hline Deqing Sanchading & ature Reserve & $\begin{array}{l}\text { - Nature reserve for } \mathrm{f} \\
\text { life nature reserve } \\
\text { - } 1.100 \text { kinds of plan } \\
\text { - } \quad \text { Sub - tropical everg } \\
\text { forest and mixed co }\end{array}$ & $\begin{array}{l}\text { rest ecosystems and wild } \\
\text { under state protection } \\
\text { een broad leaved } \\
\text { ifers. }\end{array}$ \\
\hline
\end{tabular}

ECRTD-UK https://www.eajournals.org/

Journal level DOI: https://doi.org/10.37745/bjes.2013 
Vol.10, No.2, pp. 23-40, 2022

ISSN 2054-6351 (print),

ISSN 2054-636X (online)

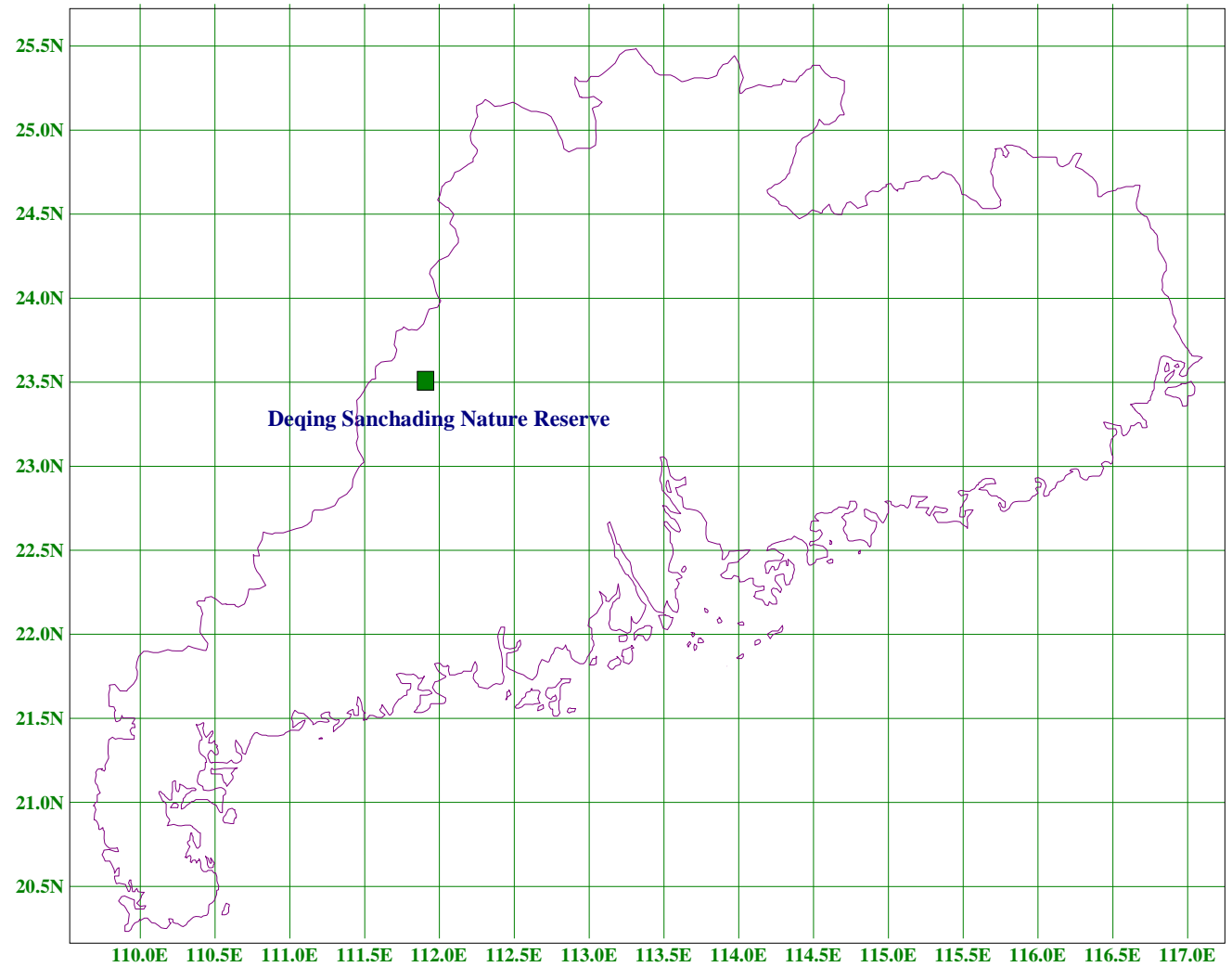

Figure 1 showing the location of Sanchading Nature Reserve Forest in Guangdong Province of China

\section{Soil sampling and chemical analysis}

After establishing forest soil sites according to stand type classification and forest management regimes in the region, soil samples were collected. The soil samples were taken in Denqing forest site whereby a $20 \times 20 \mathrm{~m}$ plot was marked out that is considered in the regional forest sites while a ten $5 \times 5 \mathrm{~m}(0.025)$ quadrants was established comprising five randomly selected soil samples in the study forest site. The surface referred as mineral soil level was categorized below $\mathrm{O}$ horizon while deep soil was considered for sampling at 0 - 25 $\mathrm{cm}$ depth (surface level) also $25-50 \mathrm{~cm}$ (deep level) using a standard 2-cm diameter stainless steel sampling probe. A total of 10 cores of each quadrant were considered. Furthermore, a two $5 \times 5 \mathrm{~cm}$ cores (strata) designated for surface and inner depth were taken within the forest site so as to determine bulk density. Soil samples at both depth samples were separated and finely mixed, air dried, grounded, and sieved as recommended [30]. The collected soil samples were finely mixed up, bagged in transparent bags, labeled and transported to the laboratory for analysis. The samples were air-dried for 48 hours, crushed with pestle and mortar then sieved to separate whole soil $(<2 \mathrm{~mm})$. Ground floor soil aggregates, plant/biomass materials (tree) components (live vegetation/roots) and stones were sieved out and removed. Soil bulk density $\left(\mathrm{P}_{\mathbf{b}}\right)$ was determined by the core method [31]. 
Vol.10, No.2, pp. 23-40, 2022

ISSN 2054-6351 (print),

ISSN 2054-636X (online)

\section{Soil physical data}

Table 2 Laboratory methods applied in determination of soil physical parameters

\begin{tabular}{lcc}
\hline \multicolumn{1}{c}{ Physical properties } & Method applied & Reference \\
\hline Natural moisture content & Gravimetric method & [32] Gardner 1986 \\
Electrical conductivity & Conductivity method & [33]1992 manual \\
pH values & Cacl $_{2}$ solution by electrode/meter & [34]McLean 1982 \\
Bulk Density & Measured by method described $^{\text {[34] Mclean 1982 }}$ \\
\hline
\end{tabular}

\section{Statistical analysis}

The statistical analyses conducted in this research arewith SPSS 11.5. A three-way analysis of variance (ANOVA) was used to testthe effects of forest type, sampling season, and soil depth on soil microbial biomass and soil chemical properties. Pearson'scorrelation analysis was used to determine whether there were significant interrelationships among the measured properties of forest soil.

\section{Statistical Review: SOC analysis applicable in soil, chemical and plant analysis}

Considering the need for testing the difference of SOC chemical composition of among three vegetation typesMultiple-response permutation procedures analysis (MRPP) was performed to test SOC chemical composition. To this, the relationship between SOC chemical composition, tree diversity, and soil physicochemical characteristics are analyzed by nonmultidimensional scaling (NMDS). Also, Pearson correlation tests are usually applied to explore the impacts of the chemical composition of SOC, tree diversity, and soil physicochemical characteristics variables on SOC chemical composition assemblages of NMDS axes. This can be achieved by calculating Pearson correlation coefficients between all of the variables and NMDS. To examine the chemical compositions of SOC, tree diversity, and soil physicochemical characteristics variables, which influenced the chemical composition of SOC. SOC evaluation parameters require assemblages, linear regressions tests to be performed which helps to further discover the potential impact of tree diversity and soil physicochemical characteristics especially on SOC chemical composition, Pearson correlations analysis is also conducted between all components of SOC chemical composition, tree species diversity, and soil physicochemical characteristics. .

\section{RESULTS AND DISCUSSION}

Table 3 Effects of plant stand types on SOC at depths $(0-25$ and $25-50 \mathrm{~cm})$, while further evaluation using soil bulk density, physical and chemical was presented at $0-50 \mathrm{~cm}$ and correlation evaluation $0-25 \mathrm{~cm}$ and $25-50 \mathrm{~cm}$ as presented respectively. Also correlation analysis of major physical properties (NMC, BD, $\mathrm{pH}$, and EC) in Deqing site (0-25, 25-50) was presented, though soil bulk density (Mg m-3) under mixed broadleaved forest management regimes. However, SOC correlation analysis was also measured over TotN, AvK, AvP and TotP 
Vol.10, No.2, pp. 23-40, 2022

ISSN 2054-6351 (print),

ISSN 2054-636X (online)

Table 3 correlation evaluation of chemical properties in Deqing site

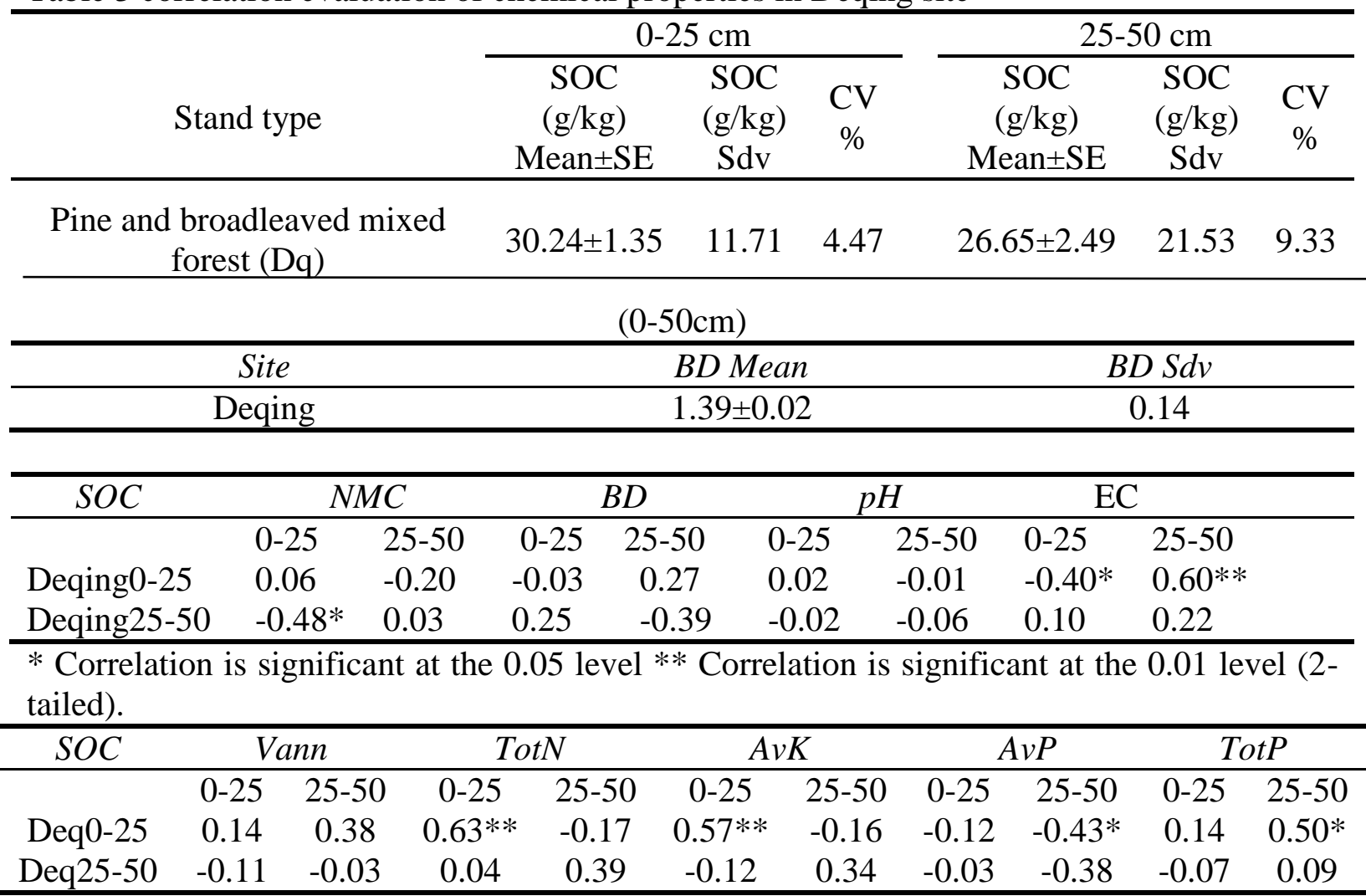

$*$ Correlation is significant at the 0.05 level ** Correlation is significant at the 0.01 level (2tailed). Deq - Deqing forest site

Influence of forest soil properties on SOC under pine and broadleaved mixed forest soil Evaluation of the influences of forest soil properties on organic carbon density and concentration pattern in table 4 showed that there were strong influences on forest soil organic carbon $(0-50 \mathrm{~cm})$ in the region. This trend is in conformity with the earlier results on specific assessment and SOC concentration pattern on each depth, forest management practices and vegetation stand types.

Table 4 Correlation analysis of the influence of forest soil properties on SOCc $(0-25 \mathrm{~cm})$ and Correlation analysis of the influence of forest soil properties on SOCd $(0-50 \mathrm{~cm})$

\begin{tabular}{|c|c|c|c|c|c|c|c|c|c|c|c|}
\hline & $S O C d$ & $N M C$ & $B D$ & $p H$ & $E C$ & $S O M$ & $A v N$ & TotN & $A v K$ & $A v P$ & TotP \\
\hline Deq & $0.97 * *$ & 0.01 & -0.19 & -0.07 & 0.00 & $1.00 * *$ & 0.07 & $0.46 * *$ & $0.41 * *$ & -0.24 & 0.12 \\
\hline \multicolumn{12}{|c|}{$\begin{array}{l}\text { * Correlation is significant at the } 0.05 \text { level } * * \text { Correlation is significant at the } 0.01 \text { level (2- } \\
\text { tailed). }\end{array}$} \\
\hline & $N M C$ & $B D$ & $p H$ & $E C$ & $S O M$ & SOCC & $A v N$ & TotN & $A v K$ & $A v P$ & TotP \\
\hline Deq & -0.09 & 0.03 & -0.12 & 0.07 & $0.97 * *$ & $0.97 * *$ & 0.13 & $0.42 * *$ & $0.37 * *$ & -0.25 & 0.16 \\
\hline
\end{tabular}


Vol.10, No.2, pp. 23-40, 2022

ISSN 2054-6351 (print),

ISSN 2054-636X (online)

The distribution and concentration pattern of SOC indicated even distribution in the mixed broadleaved forest of Deqingforest soils because of the management condition in place whereby considering suchsite with little and restricted disturbances as well as other anthropogenic influences on the soil properties.

\section{SOC concentration of specific Pine and broadleaved mixed forest soil site status}

SOC concentration evaluated at the Deqing site had $30.24 \pm 1.35(0-25 \mathrm{~cm})$ and $26.65 \pm 2.49$ $(25-50 \mathrm{~cm})$, as shown in table 5 , and by site status, it was observed that sources of pollution (however the site is classified as highly protected with no or little interference i.e. disturbance and other forms of pollutants). This is to say, that the impact of pollutants in turn may pose some constrains to nutrient status, chemical and physical soil properties, as well as forest management change.

Table 5SOC concentration evaluation in Deqing forest reserved site for $\mathrm{pH}$ and heavy metals evaluated across soil samples in the forest site, while Duncan's critical evaluation of SOC under among the forest site status were measured respectively. The effect of pollution and other forms of forest soil environment disturbances has negative impact on terrestrial ecosystems, as usually indicated critical significance using Duncan's critical statistical assessment in table 5 and evaluation of $\mathrm{pH}$ and heavy metals within the forest site as indicated in table 5 .

Table 5: Duncan's critical statistical assessment and evaluation of $\mathrm{pH}$ and heavy metals within the forest site

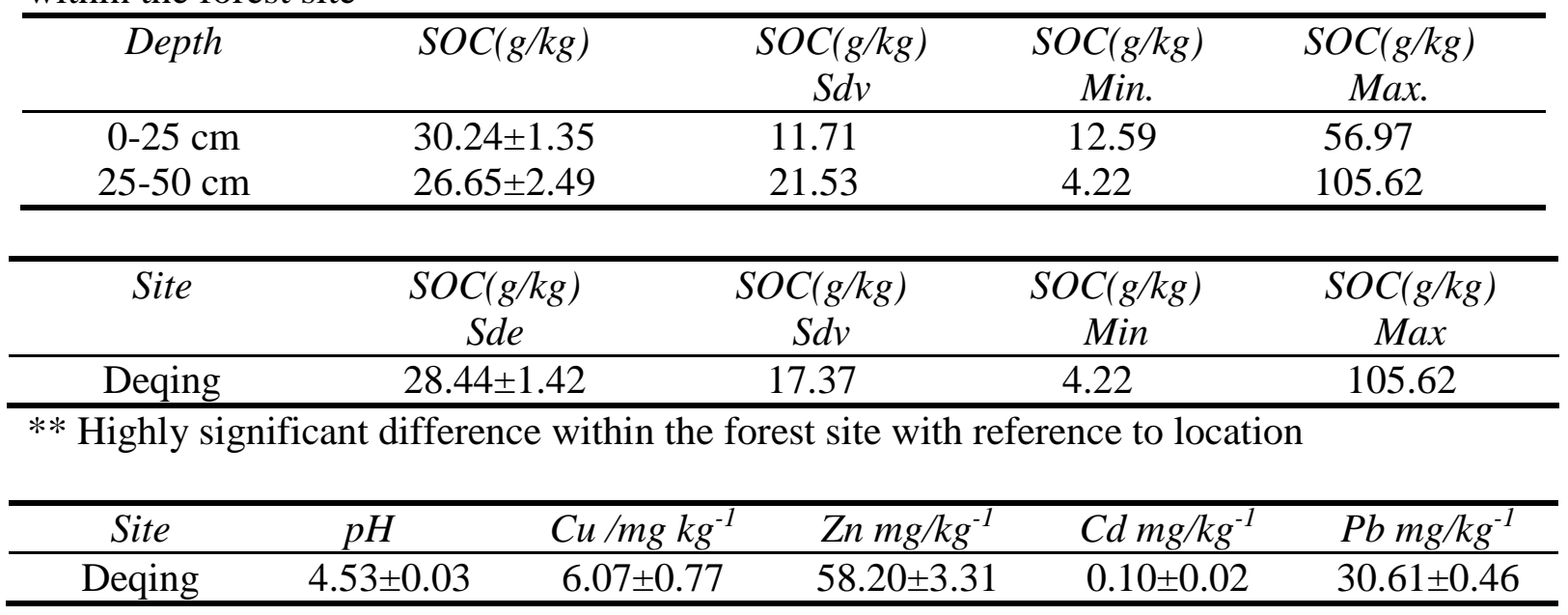

Further analysis using Pearson correlation, multiple comparisons and multiple comparisons of major chemical factors were presented in the site as in table 6 .

Table6 Pearson correlation analysis of SOC against physical properties in Deqing site

\begin{tabular}{|c|c|c|c|c|c|c|c|c|}
\hline \multirow[t]{2}{*}{ Deqing } & \multicolumn{2}{|c|}{ NMC } & \multicolumn{2}{|c|}{ BD } & \multicolumn{2}{|c|}{$\mathrm{pH}$} & \multicolumn{2}{|c|}{ EC } \\
\hline & $0-25$ & $25-50$ & $0-25$ & $25-50$ & $0-25$ & $25-50$ & $0-25$ & $25-50$ \\
\hline $0-25$ & 0.056 & -0.20 & -0.03 & 0.27 & 0.02 & -0.01 & $-0.40^{*}$ & $0.60 * *$ \\
\hline $25-50$ & $-0.478 *$ & 0.03 & 0.25 & -0.39 & -0.02 & -0.06 & 0.10 & 0.22 \\
\hline
\end{tabular}


Vol.10, No.2, pp. 23-40, 2022

ISSN 2054-6351 (print),

ISSN 2054-636X (online)

\begin{tabular}{|c|c|c|c|c|}
\hline Site & NMC & $\mathrm{BD}$ & $\mathrm{pH}$ & SOM \\
\hline $\begin{array}{c}\text { Deqing } \\
0-25\end{array}$ & $230.703 \pm 7.512 b c$ & $1.41 \pm 0.03 b c$ & $4.65 \pm 0.05$ a $98.55 \pm 11.4107$ a & $30.238 \pm 2.356 \mathbf{a}$ \\
\hline $\begin{array}{c}\text { Deqing } \\
25-50\end{array}$ & $248.103 \pm 9.137 \mathrm{ab}$ & $1.38 \pm 0.02 b c$ & $4.82 \pm 0.06$ a $67.16 \pm 9.122$ b 8 & $26.651 \pm 4.338 \mathbf{a}$ \\
\hline
\end{tabular}

Means with the same letters in a column are not significantly different $(\mathrm{P}>0.05)$

Table 7 Multiple comparisons of major chemical factors within the site and evaluation mean acidic value within the Pine and broad mixed forest regime

\begin{tabular}{ccccc}
\hline Site & SOM g/kg & SOC g/kg & AvN mg/kg & TotN g/kg \\
\hline $\begin{array}{c}\text { Deqing } \\
0-25\end{array}$ & $52.130 \pm 4.0622 \mathbf{a}$ & $30.238 \pm 2.356 \mathbf{a}$ & $109.951 \pm 10.408 \mathbf{a}$ & $2.020 \pm 0.217 \mathbf{a}$ \\
$\begin{array}{c}\text { Deqing } \\
25-50\end{array}$ & $45.946 \pm 7.4785 \mathbf{a}$ & $26.651 \pm 4.338 \mathbf{a}$ & $59.844 \pm 10.602 \mathbf{b c}$ & $1.423 \pm 0.189 \mathbf{b}$ \\
& & & & \\
\hline & Site & \multicolumn{2}{c}{$p H$ Mean } & 0.29 \\
\hline
\end{tabular}

Estimates of soil organic matter under Pine and broad mixed forestmanagement regimes

Soil Organic Matter (SOM) in table 8, evaluated within the forest site by mean value indicated that Deqing forest site (Pine and broad mixed forest) was highest (49.04 \pm 4.23$)$, followed by Nanling nature reserve (Secondary forest) 38.96 \pm 4.4 and Changtan nature reserve (non-commercial ecological forest) $35.71 \pm 2.63$ as documented by [35]. To this assertion SOM mean value (table 8 ) and SOC stocks (table 8 ) by concentration within the site showed some revealing uniqueness.

Table 8 Soil organic matter mean evaluation among the forest regimes as well as Mean SOC stocks by concentration and density among the forests sites

\begin{tabular}{ccccc}
\hline \multicolumn{2}{c}{ Site } & \multicolumn{4}{c}{ SOM Mean $(\mathrm{g} / \mathrm{kg})$} & SOM Sdv $(\mathrm{g} / \mathrm{kg})$ \\
\hline Deqing & $49.04 \pm 4.23$ & 29.94 \\
\hline \multirow{6}{*}{ Site } & SOC Mean & SOC Sdv & SOC density & SOC density \\
& $(\mathrm{g} / \mathrm{Kg})$ & $(\mathrm{g} / \mathrm{Kg})$ & Mean $(\mathrm{t} / \mathrm{hm} 2)$ & Sdv $(\mathrm{t} / \mathrm{hm} 2)$ \\
\hline Deqing & $28.44 \pm 2.46$ & 17.37 & $0.98 \pm 0.08$ & 0.57 \\
\hline
\end{tabular}

\section{Comparative analysis of SOC in Deqing Sanchading Nature Reserve (Pine and Broad mixed forest)under different depth}

Deqing Sanchading nature reserve forest site in fig.2, indicated at $0-25 \mathrm{~cm}, \mathrm{SOC}(\mathrm{g} / \mathrm{kg}): \mathrm{N}=$ 75, mean $=30.237, \mathrm{Stdv}=11.714, \max =56.97, \mathrm{~min}=12.59$ and at $25-50 \mathrm{~cm} \mathrm{SOC}\left(\mathrm{g} / \mathrm{kg}^{-}\right): \mathrm{N}$ $=75$, mean $=26.651, \mathrm{Stdv}=21.529, \max =105.62, \min =4.22$ 
Vol.10, No.2, pp. 23-40, 2022

ISSN 2054-6351 (print),

ISSN 2054-636X (online)

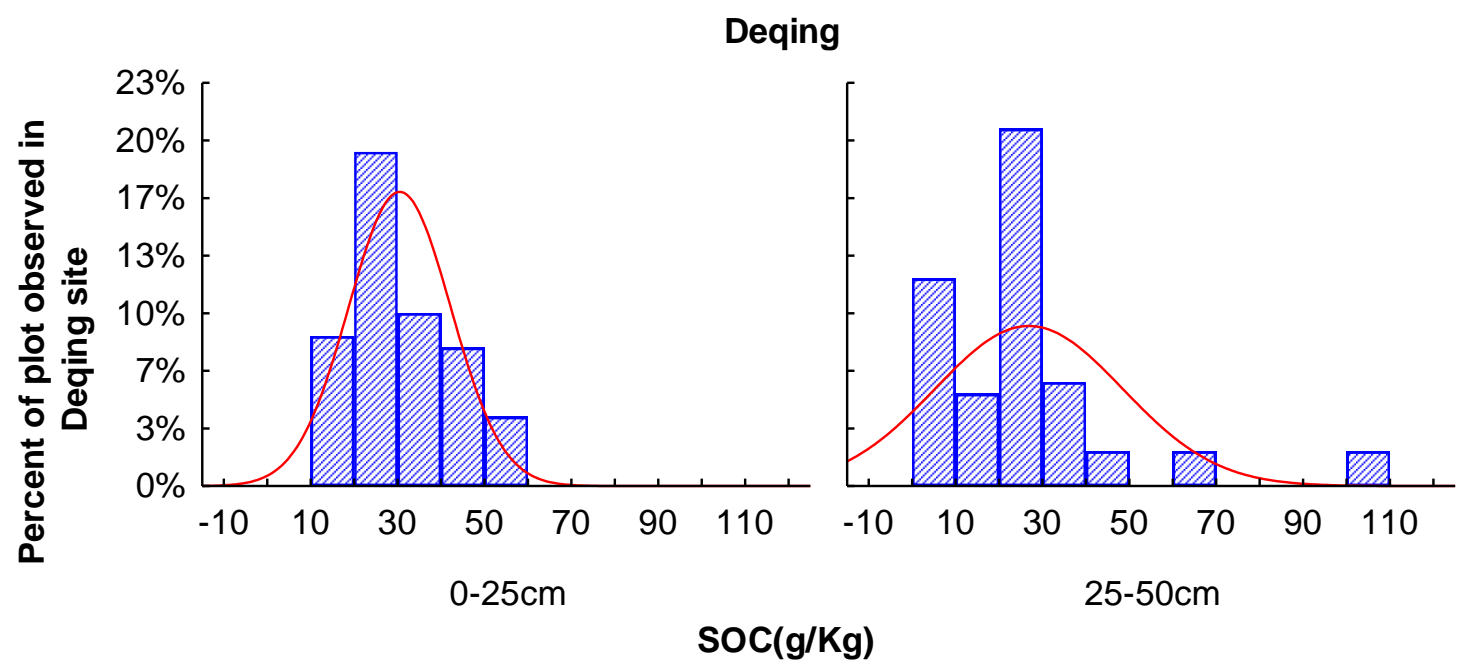

Figure 2 Deqing Sanchading nature reserve site cumulative evaluation of SOC distribution $(0-25,25-50 \mathrm{~cm}$

Further comparative analysis as in fig 4[35],SOC stocks evaluated by three management sites compared on environmental factors of physical parameters of $\mathrm{NM}, \mathrm{BD}, \mathrm{EC}$, and $\mathrm{pH}$ and documented evidences revealed that SOC and climatic variables are considerable factors among forests as in fig 3 where [36] reported SOC density (SOC amount in a particular area) during a period related to an actual measurements during another periodand was predicted on the basis of an updated ANN model where both MAT and MAP were excluded as input variables (MAT: mean annual temperature, and MAP: mean annual precipitation). In the research presentation, the thick line is the regression line, and the thin lines are the 95\% confidence interval, with linear function, goodness of fit and $P$ values described above the line as in fig 3 below. 


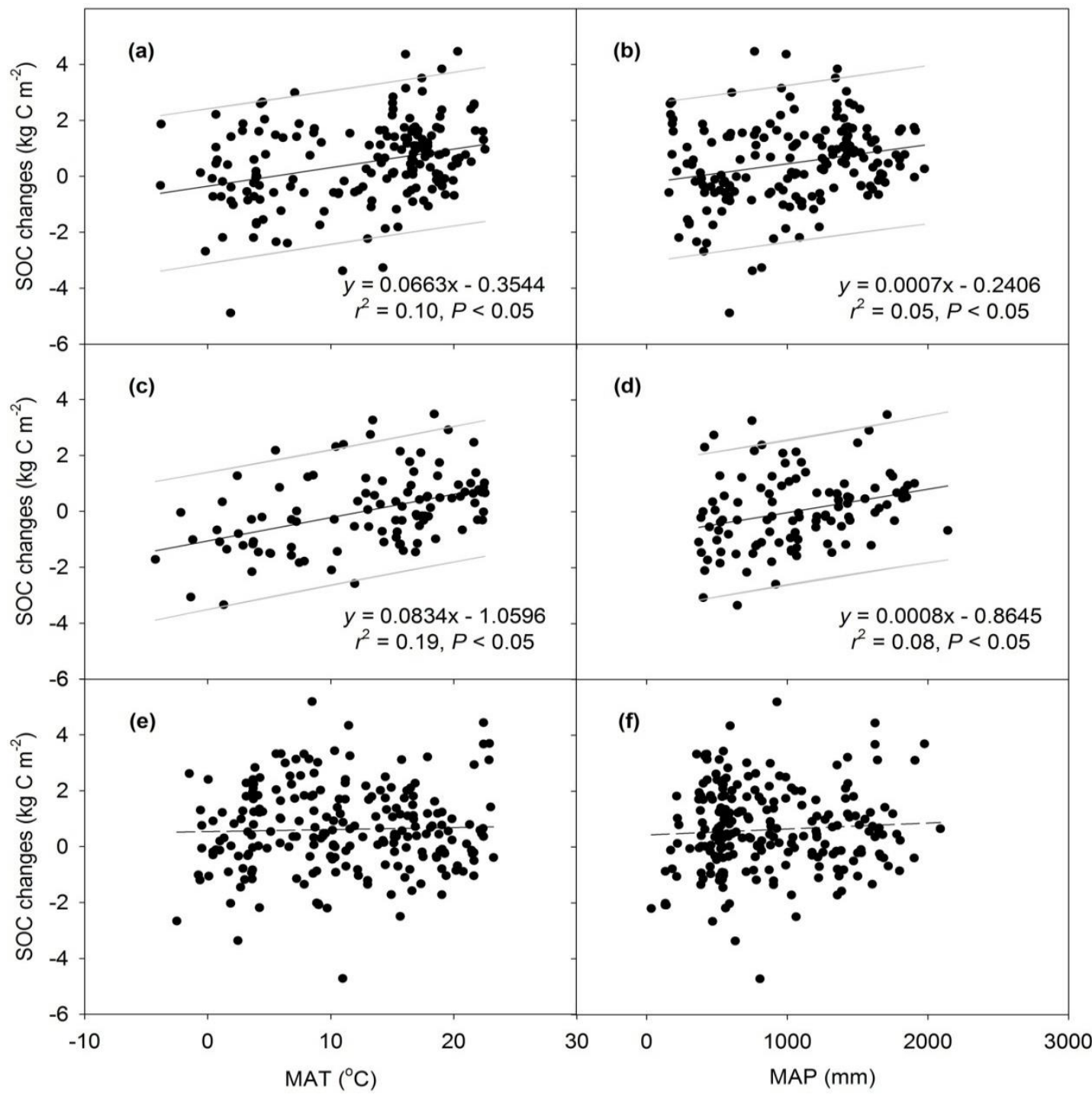

Fig. 3 Relationships between SOC changes and climatic variables across coniferous forests ab), coniferous/broadleaved mixed forests (c-d), and broadleaved forests (e-f).

Source: Guo, X. et al. Vegetation change impacts on soil organic carbon chemical composition in subtropical forests. Sci. Rep. 6, 29607; doi: 10.1038/srep29607 (2016).

Estimated forest age, stand types and pine broad leaved mixed forest regime

The estimated forest age according to available regional forest management policies and systems which is identified that the comparative forest sites have undergone some land use and forest changes over the estimated age as shown in table 9. 
Vol.10, No.2, pp. 23-40, 2022

ISSN 2054-6351 (print),

ISSN 2054-636X (online)

Table 9 Estimated forest age and management information

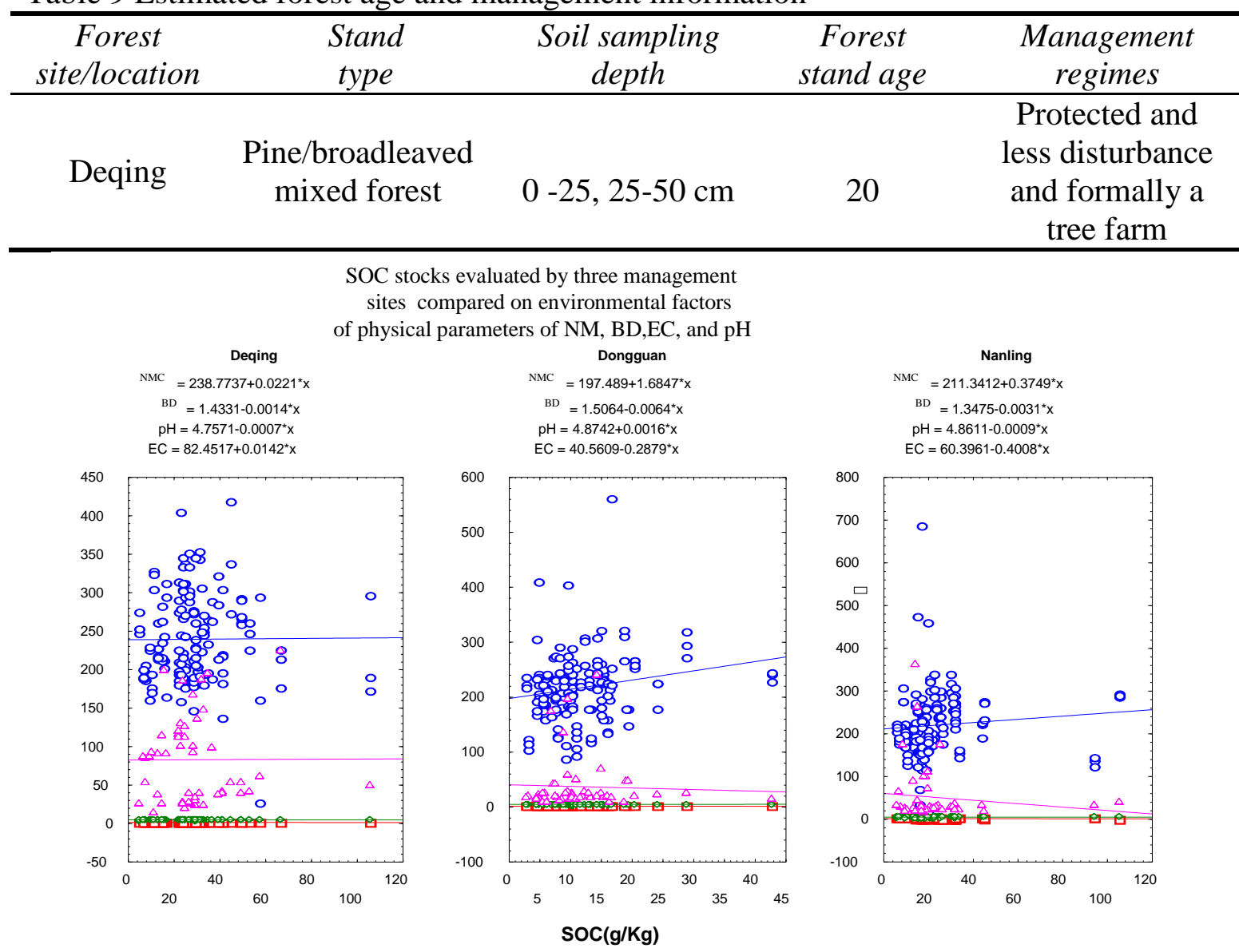

Fig 4SOC stocks evaluated by three management sites compared on environmental factors of physical parameters of $\mathrm{NM}, \mathrm{BD}, \mathrm{EC}$, and $\mathrm{pH}$

Table 10 Soil $\mathrm{pH}$, natural moisture, bulk density and electrical conductivity in secondary forest, nature reserve and mixed forest plantation

\begin{tabular}{|c|c|c|c|c|c|c|c|c|}
\hline Depth/stand type & pH Mean & $S d v$ & $\begin{array}{c}\text { Bulk } \\
\text { density } \\
\left(\mathrm{g} \mathrm{cm}^{-3}\right) \\
\text { Mean }\end{array}$ & $S d v$ & $\begin{array}{c}\text { Soil moisture } \\
\text { (\%) Mean }\end{array}$ & $S d v$ & $\begin{array}{c}E C \\
\text { Mean }\end{array}$ & $S d v$ \\
\hline \multicolumn{9}{|l|}{$0-25 \mathrm{~cm}$} \\
\hline Nature reserve & $4.81 \pm 0.06$ & 0.55 & $1.44 \pm 0.02$ & 0.13 & $218.76 \pm 6.49$ & 56.21 & $34.73 \pm 4.25$ & 36.77 \\
\hline Mixed plantation & $4.65 \pm 0.03$ & 0.26 & $1.41 \pm 0.03$ & 0.23 & $230.7 \pm 6.22$ & 53.89 & $98.55 \pm 6.7$ & 58.00 \\
\hline \multicolumn{9}{|l|}{$25-50 \mathrm{~cm}$} \\
\hline Secondary forest & $4.86 \pm 0.04$ & 0.34 & $1.33 \pm 0.02$ & 0.18 & $202.57 \pm 9.63$ & 83.42 & $45.46 \pm 8$ & 69.25 \\
\hline Nature reserve & $6.25 \pm 1.28$ & 11.09 & $1.43 \pm 0.02$ & 0.13 & $215.6 \pm 7.64$ & 66.18 & $39.66 \pm 6.48$ & 56.12 \\
\hline Mixed plantation & $4.82 \pm 0.04$ & 0.34 & $1.38 \pm 0.02$ & 0.15 & $248.1 \pm 6.98$ & 60.48 & $67.16 \pm 5.52$ & 47.83 \\
\hline
\end{tabular}


Vol.10, No.2, pp. 23-40, 2022

ISSN 2054-6351 (print),

ISSN 2054-636X (online)

\section{Effect of chemical composition of soil organic carbon (SOC) on forest ecosystems}

Globally, soil organic carbon (SOC) amounts to the largest terrestrial carbon (C) pool. Changes in SOC pool decomposition corresponds to significant changes in the atmospheric carbon $(\mathrm{C})$ concentration. This may influence and lead to strong positive feedback to climate change. SOC decomposition rates greatly associate with its chemical composition thus shifts in SOC chemical composition that affects SOC stabilization. The changes in vegetation may be as a result of the corresponding management and this factor may alter soil aggregates, and thereby which influences SOC chemical composition. Vegetation change affects and results to forest and soil degradation through alterations in a particular soil though diverse management objectives in forest ecosystems is a strong factorthat influences and affects the chemical composition of SOC. Forest soils evaluated in different forests as supported by various researches in different regions of China [35], [36] under spatial SOC from native broadleaf forests, mixed evergreen broadleaved and coniferous forests, and tea gardens shows various impact of vegetation change and anthropogenic disturbance resulting to succession and reduction on the chemical composition of SOC.SOC chemical compositions are enhanced in native broadleaf forests and mixed broadleavedand coniferous forests since vegetation (plants) play an importantrolein SOCdynamicswhile the conversion from different forests ecosystems to others has greater impactson the chemical composition of SOC than the conversion to mixed forests[36]which has been identified as a result of more intensive disturbance than conversion from native forests tomixed forests through selective deforestation as depictedin fig. 5 and fig. 6below:

Figure 5.Solid-state $3 \mathrm{C}$ NMR spectra for soil organic carbon (SOC) in three vegetation types. Source: Guo, X. et al. (2016)

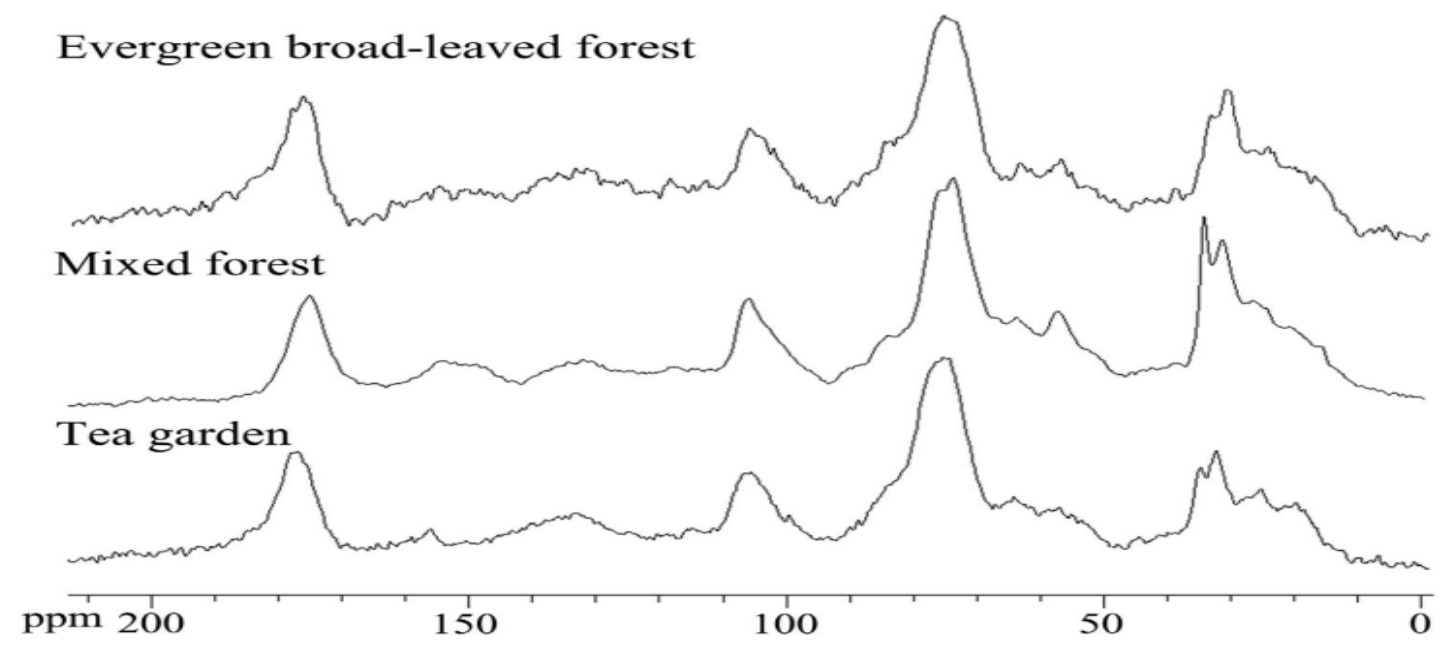


Vol.10, No.2, pp. 23-40, 2022

ISSN 2054-6351 (print),

ISSN 2054-636X (online)

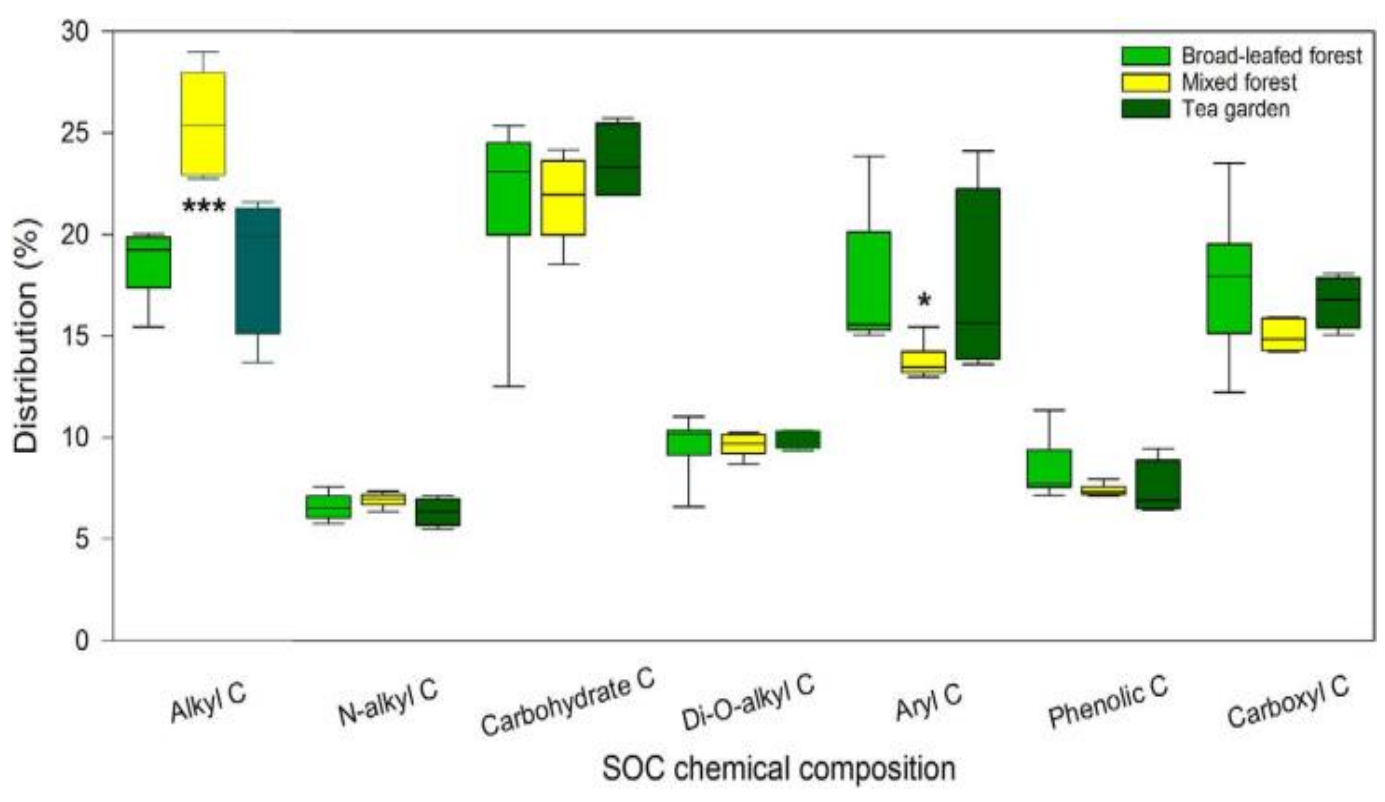

Figure 6.The chemical composition of soil organic carbon in three vegetation types

For each chemical shift range, different letters refer to a significant difference $(\mathrm{p}<0.05)$ (Guo, X. et al. (2016).Generallychemical composition of soil organic carbon (SOC) affect the global carbon cycle because it is a controlling factor in SOC decomposition rate wile forest/vegetation change is associated with long-term land use changes and correspondingly result to strong impact on the chemical composition of SOC.

\section{SOC, terrestrial ecosystems and forest management}

It has been documented that terrestrial biosphere plays greater and important role in the global carbon cycle in which the 1994 Intergovernmental Panel Assessment on Climate Change (IPCC), had made concerted efforts to improve the quantification of terrestrial exchanges and potential feedbacks from changes in global climate, changing $\mathrm{CO}_{2}$, and other emission factors. this chapter presents the key results from mixed broad forest assessment in Guangdong region of China, together with expanded discussions on SOC, forest soils, and carbon evaluation in mixed forests.Generally, it is accepted that both DOC and fragments are identified to go belowground, which makes thecontributionto SOC accumulation different while the fragments pileup on surface soil and thereby further decompose. In furtherance to this knowledge, the DOC is considered mobile across the entire soil profile and has been an important process for carbon transport within the ecosystems and the formation of SOC and in assertion to [37] [38]. The effects of forest management on soil carbon (C) and nitrogen (N) are important to understand as it is considered and has overbearing variable in the determination of soil fertility, though soil has a greater role as a source or carbon sink at a global scale. The net carbon exchange of terrestrial ecosystems provides the balance between uptake and loss mechanisms generally referred as photosynthesis and respiration under factors of diurnal, seasonal and annual variability. Available literatures confirmed that under favourable conditions, the net ecosystem flux is dominated by photosynthesis during daytime, and by respiration at night and for deciduous ecosystems in leafless periods. It is also noted that the influence of climate and growing-season period and length do in some cases shift a terrestrial ecosystem from a sink to a source of carbon,the concern on the role of soil in the 
Vol.10, No.2, pp. 23-40, 2022

ISSN 2054-6351 (print),

ISSN 2054-636X (online)

global carbon budget and effects of SOC decline on soil quality has been incorporated in international treaties. Effect of plant stand types based on broad pine and broadleaved mixed forest $(30.24 \pm 1.35,11.71$ of 4.49 coefficient variations at $0-25 \mathrm{~cm}$ depth, while $25-50 \mathrm{~cm}$ was $26.65 \pm 2.49,21.53$ at 9.33). Correlation analysis of $\mathrm{NMC}, \mathrm{BD}, \mathrm{pH}, \mathrm{EC}$ and chemical properties showed highest at $51 \mathrm{~g} * \mathrm{~kg}$ and $49 \mathrm{~g} * \mathrm{~kg}$ at both depths. Correlation analysis of the influence of soil properties on SOCc and SOCd $(0-50 \mathrm{~cm})$ showed that less disturbances and good forest management regime were in place. SOC concentration and effect of pollution and other forest soil environmental disturbances shows negative impact on terrestrial ecosystems. Duncan's critical evaluation of SOC (105.62) and heavy metals revealed $\mathrm{Zn}$ to be highest (58.20 \pm 3.37$)$. Cumulative evaluation of SOC distribution further supports that pine and broadleaved mixed forest stand exhibits high potential of carbon sequestration. This study calls for cautions in large-scale conversions of the native forests to any plantations as a forest management practice on concerns of sustaining soil productivity.

Impact of the study on forest management in general and carbon management in the light of Kyoto protocol

This study has positioned a strong background that the Kyoto protocol includes rules for the accounting of GHG emissions from Land use, Land-use Change and Forestry (LULUCF) whereby this study is in line to such Kyoto targets. To this accounting of the advantage of good forest management regime, forest policy for afforestation, reforestation, and deforestation whereby countries especially developing countries can be credited for the net GHG flow from afforestation, reforestation and deforestation. This study in Deqing Sanchading nature reserve provides an enhancement of carbon storage in forests. Generally, planting forests and management of forest regime absorb excess $\mathrm{CO}_{2}$ in the atmosphere which is an option in the context of harnessing forests for curbing climate change. This study strongly supports and enhancing carbon storage in forests and their products. Planting and managing forests with the interest to absorb excess $\mathrm{CO}_{2}$ in the atmosphere is the good option that has been for curbing climate change. Generally, carbon offset plantings is a focal projection and globally implemented under the Kyoto Protocol.Forest management schemes and tree planting goes beyond climate change rather plantations, agroforestry systems, urban forests, silvicultural and management options exists and clamored in developing nations for the purpose of enhancing carbon uptake and storage in forest ecosystems. Broad pine and broadleaved mixed forest as well as even-aged forests are considered to attain high sequestration rates thereby immature forests is accounted to act as carbon sinks especially in East Asia and Europe. Kyoto protocol encourages forests and forest management. Forest management provides option in which carbon accounting under the Kyoto Protocol the monetary equivalent of carbon stocks will favor the developing and less industrialized nations referred as carbon offset.

\section{CONCLUSION}

SOC and SOM are major and vital source and sink of atmospheric CO2 on several time scales. Carbon is largely stored in organic forms that rapidly exchanges with atmospheric CO2 mostly in soils (forest soils) and other mediums. Generally, C turnover and its control are mostly influenced by such factors as temperature, moisture, vegetation and forest 
Vol.10, No.2, pp. 23-40, 2022

ISSN 2054-6351 (print),

ISSN 2054-636X (online)

management. This is to say, that soils and forest management are not sinks of carbon in which the medium gain and loss $\mathrm{C}$. The main factors of $\mathrm{C}$ disturbance and cycling include forest management, fires, floods, deforestation, reforestation, agricultural practices and drainage. The disturbances and affects of $\mathrm{C}$ inputs and losses to soil occur as a result of changing vegetation, soil structure, temperature, water balance, nutrient availability and forest management. Rates of organic $\mathrm{C}$ stocks are responses to these factors. Vegetation and plant species control $\mathrm{C}$ storage in which net primary productivity of vegetation will determine the rate of $\mathrm{C}$ input to SOM. This chapter of broad pine and broadleaved mixed forest strongly supports that vegetation and plant species also controls the structure and determine the decomposability of OM that is added to soils. This study recommends and opens further studies in forest management models under different forest regimes and carbon accumulations.

\section{Acknowledgments}

We wish to express our gratitude to the Government of the Peoples Republic of China, through the China Scholarship Council Beijing that provided the various enablement and funds to cover the field and laboratory expenses throughout the period of the research. We also appreciate all authors whose citation formed a strong background of this book chapter.

\section{References}

[1] Schlesinger, W.H., 1990. Evidence from chronosequence studies for a low carbon stora potential of soils. Nature 348, 232-234.

[2] Schlesinger, W.H., 1977. Carbon balance in terrestrial detritus. Annual Review of Ecologyand Systematics 8, 51-81.

[3] PostW.M, EmanuelW.R, ZinkeP.J, StangenbergerAG,1982.Soil carbon pools and world lifezones. Nature UK,298:156-159

[4] Christensen, B., and A. E. Johnston 1997. In E.G. Gregory and M.R. Carter (ed) Soil quality for crop production and ecosystems health. Dev. in Soil Sci. 25. Elsevier, Amsterdam: 399 - 430

[5]Carter, M.R. 2002. Soil quality for sustainable land management: Organic matter and aggregation interactions that maintain soil functioning. Agron. J., 94:38-47

[6]Arshad, M.A., and G.M. Coen. 1992. Characterization of soil quality Physical and chemical criteria. Am. J. Alternative Agric., 7:5-12

[7] Yakovchenko, V.P., L.J. Sikora, and P.D. Millner., 1998. Carbon and nitrogen mineralization of added particulate and macroorganic matter. Soil Biol. Biochem., 30:2139-2146

[8]Post W. M., R. C, Izaurralde, L. K. Mann and N. bliss, 2001. Monitoring and Verifying Changes of Organic Carbon in Soil. Climate Change, Kluwer Academic Publishers, 51: 73 - 99

[9] Grierson, P.F., Adams, M.A., Attiwill, P.M., 1991. Carbon storage in soil and in forest products. School of Botany, University of Melbourne, Parkville, Victoria, 44

[10]Johnson, D.W., 1992. Effects of forest management on soil carbon storage. Water Soil and Air Pollution,64: 83-120 
Vol.10, No.2, pp. 23-40, 2022

ISSN 2054-6351 (print),

ISSN 2054-636X (online)

[11]Harrison, A.F., Howard, P.J.A., Howard, D.M., Howard, D.C. and Hornung, M., 1995. Carbon storage in forest soils. Forestry,68: 335-348

[12]Tate, K.R., Giltrap, D.J., Claydon, J.J., Newsome, P.F., Atkinson, I.A.E., Taylor, M.D.and Lee, R., 1997. Organic carbon stocks in New Zealand's terrestrial ecosystems. J. Royal Soc. N.Z.,27: 315-335 Tate et al., (1977)

[13]Lal, R. J.M. Kimble, R.F. Follett and C.V. Cole. 1998. The potential of U.S. cropland to sequester carbon and mitigate the greenhouse effect. Ann Arbor Press, Chelsea, MI, 128

[14] Paustian, K., Andr`en, O., Janzen, H.H., Lal, R., Smith, P., Tain, G., Tiessen, H., van Noordwijk, M. and Woomer, P.L., 1998. Agricultural soils as a sink to mitigate CO2emissions. Soil Use and Management,13: 230-244

[15] Sampson, R.N. and Scholes, R.J., 2000. Additional human-induced activities - Article 3.4. in R.T.Watson, I.R. Noble, B. Bolin, N.H. Ravindranath, D.J.Verardo and D.J.Dokken (eds.), Land Use, Land-Use Change, and Forestry, Cambridge, Published for the Intergovernmental Panel on Climate Change by Cambridge University Press, 183-281

[16] Bruce, J.P., M. Frome, E. Haites, H. Janzen, R. Lal, and K. Paustian. 1999. Carbon sequestration in soils. J. Soil Water Conserv., 54: 382-389

[17] Lal, R. J.M. Kimble, R.F. Follett and C.V. Cole. 1998. The potential of U.S. cropland to sequester carbon and mitigate the greenhouse effect. Ann Arbor Press, Chelsea, MI, 128

[18] Lal, R., R.F. Follett, J. Kimble, and C.V. Cole. 1999. Managing U.S. cropland to sequester carbon in soil. J. Soil Water Conserv., 54: 374-381

[19] Paustian, K., Andr`en, O., Janzen, H.H., Lal, R., Smith, P., Tain, G., Tiessen, H., van Noordwijk, M. and Woomer, P.L., 1998. Agricultural soils as a sink to mitigate CO2 emissions. Soil Use and Management,13: 230-244

[19] Paustian, K., O. Andren, H.H. Janzen, R. Lal, P. Smith, G. Tian, H. Tiessen, M. Van Noorwijk, and P.L. Woomer.,1997a. Agricultural soils as a sink to mitigate CO2 emissions. Soil Use Manage., 13: 230-244

[19] Paustian, K., H.P. Collins, and E.A. Paul., 1997b. Management controls on soil carbon. In E.A.Paul et al. (ed.) Soil organic matter in temperate agroecosystems: Long-term experiments in North America. CRC Press, Boca Raton, FL, 15-49

[20] Sperow, M., M. Eve, and K. Paustian., 2003. Potential C sequestration on U.S. agricultural soils. Clim. Change, 57:319-339

[21] Birdsey, R.A., and G.M. Lewis. 2003. Carbon in United States forests and wood products,

1987-1997: State-by-state estimates. Gen. Tech. Rep. NE-310. USDA For. Serv.,

Northeastern Research Station. Newtown Square, PA.

[22] Heath, L., J. Smith, and R.A. Birdsey. 2003. Carbon trends in U.S. forestlands: A context forthe role of soils in forest carbon sequestration. In J.M. Kimble et al. (ed.) The potential of U.S. forest soils to sequester carbon and mitigate the greenhouse effect. CRC Press, Boca Raton, FL.

[23] Paul, K.I., P.J. Polglase, J.G. Nyakuengama, and P.K. Khanna., 2002. Change in soil carbonfollowing afforestation. For. Ecol. Manage., 168:241-257 
Vol.10, No.2, pp. 23-40, 2022

ISSN 2054-6351 (print),

ISSN 2054-636X (online)

[24] Conant, R. T., and K. Paustian. 2002. Spatial variability of soil organic carbon: Implications for detecting change at different scales. Environmental Pollution, 116:127-135

[25] Conant, R. T., G. Smith, and K. Paustian. 2003. Spatial Variability of Soil Carbon in Forested and Cultivated Sites: Implications for Change Detection. Journal of Environmental Quality, 32:278-286

[26] Conant, R. T., S. J. Del Grosso, W. J. Parton, and K. Paustian. 2004. Nitrogen pools andfluxes in grassland soils sequestering carbon. Nutr. Cycl. Agroecosys.

[26] Conant, R. T., and K. Paustian. 2002. Spatial variability of soil organic carbon: Implications for detecting change at different scales. Environmental Pollution , 116:127-135 ,,Conant et al., 2001).

[27] Bolin, B, R Sukumar, P Ciais, W Cramer, P Jarvis, HS Kheshgi, C Nobre, S Se-menov and WLSteffen. 2000. Land Use, Land Use Change, and Forestry: an IPCC Special Report. In: Watson, RT, IR Noble, B Bolin, NH Ravindranath, DJ Ver-ardo and DJDokken (Ed), Cambridge University Press, 23-51

[28] IPCC Special Report on Land Use, Land-use Change and Forestry (SRLULUCF). Bolin B, Sukumar RP, Ciais W, et al., 2000. Global Report. In: Watson, RT, IR Noble, B Bolin, NH Ravindranath, DJ Ver-ardo and DJ Dokken (Ed), Cambridge University Press, 23-51

[29] Jonathan A Foley, Marcos Heil Costa, Christine Delire, Navin Ramankutty, and Peter Snyder, 2003. Green surprise? How terrestrial ecosystems could affect earth's climate Front Ecol Environ. The Ecological Society of America, 1(1): 38-44

[30] Nelson, D.W. and L.E. Sommers., 1996. Total carbon, organic carbon, and organic matter.In: Methods of Soil Analysis, Part 2, $2^{\text {nd }}$ ed., A.L. Page et al., Ed. Agronomy. Am. Soc. of Agron.,Inc. Madison, WI, 9:961-1010

[31] Blake, G.R., and K.H. Hartge, 1986, Bulk Density, in A. Klute, ed., Methods of Soil Analysis,Part I. Physical and Mineralogical Methods: Agronomy Monograph no. 9 (2nd ed.), ASA and SSSA, Madison, WI: 363-375

[32] Gardner, W.H. 1986. Water content. In A Klute (ed) Methods of Soil Analyses. part 1. $2^{\text {nd }}$ ed. Agron. Monogr. No.9 ASA and SSSA Madison; WI, 493 - 544

[33] Manual: Soil Survey Staff, 1992. National Soil Survey Laboratory Methods Manual (SInvestigation Report No.42. US Government Printing Office, Washington. DC.

[34]McLean E. O, 1982. Soil pH and lime requirement in pages, A.L. Miller, R.H and Keeney, D. R (eds). Methods of Soil Analyses; Part 2. Chemical and Microbiological properties Agronomy No. 9 2nd edition. Madison, Wisconsin, 199 - 225

[35] Egbuche C. T (2009). Spatial variability of Soil Organic Carbon (SOC) under different forestmanagement regimes and their carbon sequestration potential in Guangdong Province China (Unpublished Thesis for the Doctor of Philosophy in Forest Ecology of the South China Agricultural University Guangzhou)

[36] Guo-Yi Zhou, Yu-Hui Huang a,b, Yue-Lin Li a , Yin Xiao a,b , Katherine O. Wenigmann c , De-Qiang Zhanga, Mike Wenigmann, Xu-Li Tang a , Ju-Xiu Liu a. Vegetation change impacts onsoil organic carbon chemical composition in subtropical forests. Sci. Rep. 6, 29607; doi: 10.1038/srep29607 (2016). 
British Journal of Environmental Sciences

Vol.10, No.2, pp. 23-40, 2022

ISSN 2054-6351 (print), ISSN 2054-636X (online)

[37]Michalzik, B., Kalbitz, K., Park, J.H., Solinger, S., Matzner, E., 2001. Fluxes and concentrations of dissolved organic carbon and nitrogen - a synthesis for temperate forests.Biogeochemistry 52, 173-205.

[38]Neff, J.C., Asner, G.P., 2001. Dissolved organic carbon in terrestrial ecosystems: synthesis and a model. Ecosystems 4, 29-48. 